\title{
Markovian Decision Modeling in Dam Projects - Niger Delta River Basin
}

\author{
Dr. Eme Luke Chika, (B.Sc, PGD, PGDE, M.Eng, Ph.D), \\ Civil Engineering Department, Chukwuemeka Odumegwu Ojukwu University \\ (formerly Anambra State University), Uli - Nigeria. \\ Leeworks2002@yahoo.com \\ Ohaji Evans, (B.Eng, M.Eng) \\ Rural Infrastructural Engineer, Implementation Field Office, \\ Niger Delta Support Programme Component, Imo State, Nigeria. \\ evansohaji@gmail.com
}

\begin{abstract}
This paper studied simulation modeling in Markovian Decision theory and its application in decision making as well as planning in water resources and environmental engineering. The research objectives deals with the multiobjective values of a River basin for its wide range of purposes such as Economic Efficiency, Regional Economic distribution, State Economic distribution, Social Well-being, and Environmental Quality control. In line with foregoing objectives, the researchers aim at achieving the following: (i) Measures the magnitude of the difference between alternative actions (ii) to present a framework for considering decision making under uncertainty. (iii) to evaluate the optimal policy or strategy or action that maximizes the expected benefit in the River Basin within the available limited resources and funds over the planning period of a course of action or alternatives. The Methodology applied involved Markovian decision model method for River basin. Data collection was based on technical literatures from books, journals, and news papers, River Basin Engineering Development, Parastatals. The analysis and presentation of results were based on simulation of Markovian Models. Furthermore, Contingency association, Chi-square, Pearson Product Moment Correlation were carried out as interaction, reliability and validity tests. However, simulating the river basin variables using Markov chain Homogeneous analysis and policy iterations resulted to a decision policy of allocating resources to the river basin objectives based on a federal government budgetary appropriation of 100 billion Naira. In conclusion the model had policy decision made as follows: Economic Efficiency [64\%], Regional Economic Distribution [9\%], State Economic Distribution [19\%], Social Well-Being [5\%] and Environmental Control [3\%] [see Figure 1 and 2]. The results indicate that Markov Chain can be successfully applied in optimum policy investment decision making in multi-objective water resources management.
\end{abstract}

Keywords: Investment, Optimum, Policy Decision, Dam -projects.

DOI: $10.7176 / \mathrm{CER} / 11-2-10$

Publication date:March $31^{\text {st }} 2019$

\subsection{Introduction}

Numerous major multiple-purpose reservoir systems have been constructed throughout the nation during the past several decades. Public needs and objectives and many factors affecting operation of these reservoirs change over time. Reservoir system operations are complex and often offer substantial increases in benefits for relatively small improvements in operating efficiency. Consequently, evaluation of refinements and modifications to the operations of existing reservoir systems is becoming an increasingly important activity. However, Reservoir operation for municipal and industrial water supply is based on meeting demands subject to institutional constraints related to project ownership.

However, against the foregoing the research work was initiated out of the concern of allocating budgetary resources to the various river basin purposes for functionality requirement as well as sustainability of the system arrangement.

Statement of Problem: The research will proffers' solution on the allocation of resources to the multi-purpose dam projects such as Power generation, Navigation, water supply, Tourism, and Flood control, in the Niger Delta River Basin using Markov Modeling. In line with foregoing objectives, the research aim to achieve the following:

- $\quad$ To present selected empirical results of a study employing decision-making theory as a framework for considering decision making under uncertainty. 
- $\quad$ To evaluate the optimal policy or strategy or action that maximizes the expected yield of the River Basin purposes

Area of Study:The study area is the Niger delta river basin that lies between $6.83 \mathrm{~N}$ and $6.75 \mathrm{E} ; 5.38 \mathrm{~S}$ and $5.37 \mathrm{~W}$. Niger delta basin development authority is a service -oriented organization that is positioned to meet the water requirements of stakeholders in the most satisfactory and cost effective manner, while ensuring good quality and sanitation and paying adequate attention to preservation of the ecosystem, using proven technology and a well-motivated force[NDBDA MISSION]. In terms of geographical coverage it serves Rivers state, Bayelsa and Delta states. The three states have an estimated population of 10.7 Billion people.

\subsection{Methodology}

Under this section, the researcher identified estimation methods of the two major parameters of river basin indicators and the Markova method of application as follows:

\section{Estimating Multipurpose Benefits}

There are six data categories that structure the multipurpose benefits framework. These categories are referred to herein as "uses", and they represent a culmination of operations and services made possible due to existence of a reservoir. These uses are broadly classified to identify categories associated with a reservoir project, and serve as a foundation for assessing collective and inter-dependent relationships (Marisol Bonnet et al, 2015):

i. Hydropower: Operation and use of generating facilities and/or equipment for producing power by the sole source of water.

ii. Flood Control: Dams that facilitate the prevention and/or lessen the severity of flood damage to valuable resources within a flood basin.

iii. Water Transport\&Navigation: The operation and control of locks to facilitate the transportation of goods via inland waterways.

iv. Recreation\& Tourism: The use of water bodies (reservoirs or rivers) for physical and recreational activities (boating, fishing, swimming, etc.).

v. Water Supply: Public and private withdrawals of water used for consumption, municipal, and industrial needs.

vi. Irrigation: The withdrawal and use of water from reservoirs to meet the needs and requirement for crop and plant irrigation to sustain growth and production.

Based on the availability of both public and proprietary data, the following represent the methodologies used to compute the economic benefit of each multipurpose use.

\subsection{Markovian Simulation Method}

The method of Markov chain applied in this research work is homogeneous Markov chain one that does not evolve in time; that is, its transition probabilities are independent of the time step n. Then we have the " $n$ step" transition probabilities as stated below:

and we have

$$
p_{i j}^{(0)}=\left\{\begin{array}{ll}
1 & : i=j \\
0 & : i \neq j
\end{array} \quad p_{i j}^{(m)}=P\left(X_{n+m}=j \mid X_{n}=i\right)\right.
$$

Equation 1

Now we can define a

Theorem.Chapman-Kolmogorov equation.

theorem.

$$
p_{i j}^{(m)} \sum_{k \in Z} p_{i k}^{(r)} p_{k j}^{(m-r)} \forall r \in \mathbb{N} \cup\{0\}
$$

Proof.

$$
\begin{aligned}
p_{i j}=P\left(X_{m}=j \mid X_{0}=i\right) & =\sum_{k \in Z} P\left(X_{m}=j, X_{r} k \mid X_{o}=i\right) \\
& =\sum_{k \in Z} P\left(X_{m}=j \mid X_{r}=k, X_{0}=i\right) P\left(X_{r}=k \mid X_{0}=i\right) \\
& =\sum_{k \in Z} P\left(X_{m}=j \mid X_{r}=k\right) P\left(X_{r}=k \mid X_{0}=i\right) \\
& =\sum_{k \in Z} p_{i k}^{(r)} p_{k j}^{(m-r)}
\end{aligned}
$$

Equation 2

We can write this as a matrix for convenience: 


$$
\mathbf{P}^{(m)}=\left(\left(p_{i j}^{(m)}\right)\right)
$$

Corollary.

$$
\mathbf{P}^{(m)}=\mathbf{P}^{m}
$$

Proof. Chapman-Kolmogorov in matrix form gives us

$$
\begin{aligned}
\mathbf{P}^{(m)} & =\mathbf{P}^{(r)} \mathbf{P}^{(m-r)} \forall r \in \mathbb{N} \cup\{0\} \\
\mathbf{P}^{(2)} & =\mathbf{P} \times \mathbf{P}=\mathbf{P}^{2} \\
\mathbf{P}^{(3)} & =\mathbf{P} \times \mathbf{P}^{2}=\mathbf{P}^{3} \\
\mathbf{P}^{(m)} & =\mathbf{P}^{m}, m \geq 2, \text { then } \\
\mathbf{P}^{(m+1)} & =\mathbf{P} \times \mathbf{P}^{m}=\mathbf{P}^{m+1}
\end{aligned}
$$

Equation 4

Several definitions

A Markov Chain iscompletely determined by its transition probabilities and its initial distributionn. An initial distribution is a probability distribution

$$
\left\{\pi_{i}=P\left(X_{0}=i\right) \mid i \in \mathbb{Z}\right\}
$$

such that

$\sum_{i} \pi_{i}=1$.

A distribution is stationary if it satisfies $\pi=\pi \mathrm{P}$. The period ofstate $\mathrm{i}$ is defined as

$$
d_{i}=\operatorname{gcd}\left\{m \in \mathbb{Z} \mid p_{i i}^{(m)}>0\right\}
$$

Equation 7

that is, the ged of the numbers of steps that it can take to return to the state. If $d i=1$, the state is aperiodic- it can occur at non-regular intervals.

A state $\mathrm{j}$ is accessible from a state $\mathrm{i}$ if the system, when started in $\mathrm{i}$, has a nonzero probability of eventually transitioning to $\mathrm{j}$, or more formally if there exists some $\mathrm{n} \geq 0$ such that

$$
\operatorname{Pr}\left(X_{n}=j \mid X_{0}=i\right)>0 \text {. }
$$

We write this as $(\mathrm{i} \rightarrow \mathrm{j})$.We define the first-passage time (or "hitting time") probabilities

$$
f_{i j}^{(m)}=P\left(X_{m}=j, X_{k} \neq j, 0<k<m-1 \mid X_{0}=i\right), i, j \in \mathbb{Z} .
$$

Equation 8

that is, the time step at which we first reach state j.We denote theexpected "return time" w

$$
\mu_{i j}=\sum m=1^{\infty} m f_{i j}^{(m)}
$$

Equation 9

A state isrecurrent if

$$
\sum_{m=1}^{\infty} f_{i j}^{(m)}=1
$$

(and transient if the sum is greater than 1).

It is positive-recurrent if $\mu \mathrm{ii}<\infty$. That is, we expect to return to the state in a finite number of time steps. Fundamental Theorem of Markov Chains

Theorem. For any irreducible, aperiodic, positive-recurrent Markov chain P there exists a unique stationary distribution $\{\pi \mathrm{j}, \mathrm{j} \in \mathrm{Z}\}$.

Proof. We know that for any m,

$$
\begin{array}{lll}
\sum_{i=0}^{m} p_{i j}^{(m)} \leq \sum_{i=0}^{\infty} p_{i j}^{(m)} \leq 1 . & \text { Equation } 12 \\
\lim _{m \rightarrow \infty} \sum_{i=0}^{m} p_{i j}^{(m)}=\sum_{i=0}^{\infty} \pi_{j} \leq 1 . & \text { If we take the limit as } \mathrm{m} \rightarrow \infty: & \text { Equation } 13
\end{array}
$$

This implies that for any M, 
Now we can use Chapman-Kolmogorov:

$$
p_{i j}^{(m+1)}=\sum_{i=0}^{\infty} p_{i k}^{(m)} p_{k j} \geq \sum_{i=0}^{M} p_{i k}^{(m)} p_{k j}
$$

andtake the limit again as $\mathrm{m}, \mathrm{M} \rightarrow \infty$

$$
\pi_{j} \geq \sum_{k=0}^{\infty} \pi_{k} p_{k j}
$$

For the purpose of this research work Homogeneous Markov Chain was adopted, which stated as follows:

The matrix $\mathrm{P}$ is called a homogeneous transition or stochastic matrix because all the transition probabilities Pijare fixed and independent of time. The probability Pij must satisfy the conditions.

$\sum \mathrm{Pij}=1$, for all I

$P i j \geq 0$ for all $I$ and $j$

\subsection{Data Estimation, Analysis and Optimization}

Determination of benefits to purposes under various objectives in a multi-purpose/multi-objective Water Resources Project Planning:

At the onset of planning of multipurpose water resources project, it is necessary to declare the objectives against which efforts is being geared for their achievement, this serve as a criterion for measuring the projected end product of the planning process.

The main objective that can come into play in a multi-objective water resources development are (1) economic efficiency (economic optimization), (2) Regional economic redistribution, and (3) Social well-being. Any other objective can be incidental on the above three.

\subsection{Application of Markov Theory in Multi-Purpose Multi-Objective Projects Optimization}

Let's consider Federal Government Allocation to Niger Delta River Basin whereN100 billion is to be spent on a multi-purpose/multi-objective water resources development project. The purposes of interest are Navigation, Tourism, Flooding, Hydro-electric power generation and water supply. The objectives to be simultaneously achieved at optimum level are economic efficiency, regional economic redistribution, State Economic distribution, social well-being and Environmental quality.

The problem then becomes how to apportion the $\mathbf{N 1 0 0}$ billion developmentfund among the various purposes so as to optimize the objective even under the worst situation of conflict.

A benefit study of the five purposes under each of the five objectives was carried out. The results being the figures as shown in table 5.1. What we have by the table is basically a Matrix situation that satisfies the homogeneous Markov chain. 
Table 1 Benefit to N100 Billion under various objectives [N X 10]

\begin{tabular}{|l|l|l|l|l|l|} 
State of Nature & \multicolumn{5}{|c|}{ Objectives } \\
\hline Purposes & $\begin{array}{l}\text { Economic } \\
\text { efficiency } \\
\text { allow[Billion } \\
\text { Naira] }\end{array}$ & $\begin{array}{l}\text { Regional } \\
\text { economy }\end{array}$ & $\begin{array}{l}\text { State } \\
\text { economic } \\
\text { distribution }\end{array}$ & $\begin{array}{l}\text { Social well- } \\
\text { being }\end{array}$ & Environment \\
\hline Navigation & 2 & 0.3 & 0.89 & 0.2 & 0.1 \\
\hline Tourism & 30.5 & 0.68 & 0.75 & 0.8 & 0.45 \\
\hline Flooding & 20.3 & 1 & 0.65 & 0.75 & 0.35 \\
\hline Hydropower & 1.7 & 2 & 0.9 & 0.45 & 0.59 \\
\hline Water supply & 1.4 & 0.75 & 0.8 & 0.35 & 0.74 \\
\hline
\end{tabular}

Table 5.1 above is in matrix form and is converted into homogeneous transition or stochastic matrix to satisfy Markov Chain process where the probability Pij must satisfy the conditions:

$\sum \mathrm{Pij}=\mathbf{1}$, for all $\mathrm{I} ; \mathrm{Pij} \geq \mathbf{0}$ for all $\mathrm{I}$ and $\mathrm{j}$

Table 2: Represents Probability of "ij" in table 1

\begin{tabular}{|l|l|l|l|l|l|}
\hline State of Nature & \multicolumn{5}{|c|}{ Objectives } \\
\hline Purposes & $\begin{array}{l}\text { Economic } \\
\text { efficiency } \\
\text { allow[Billion } \\
\text { Naira] }\end{array}$ & $\begin{array}{l}\text { Regional } \\
\text { economy }\end{array}$ & $\begin{array}{l}\text { State } \\
\text { economic } \\
\text { distribution }\end{array}$ & $\begin{array}{l}\text { Social } \\
\text { wellbeing }\end{array}$ & Environment \\
\hline Navigation & 0.573066 & 0.08595989 & 0.25501433 & 0.0573066 & 0.0286533 \\
\hline Tourism & 0.919228 & 0.02049427 & 0.02260398 & 0.0241109 & 0.01356239 \\
\hline Flooding & 0.880694 & 0.04338395 & 0.02819957 & 0.032538 & 0.01518438 \\
\hline Hydropower & 0.301418 & 0.35460993 & 0.15957447 & 0.0797872 & 0.10460993 \\
\hline Water supply & 0.346535 & 0.18564356 & 0.1980198 & 0.0866337 & 0.18316832 \\
\hline
\end{tabular}

Converting Table 5.2 to a linear equation as following:

The above Matrix problem can be solved from the maximize point of view with the understanding that all purposes should be undertaken at positive level even under the worst circumstances or condition.

Let probability $\pi 1$ represent Navigation

Let probability $\pi 2$ represents Tourism

Let probability $\pi 3$ represents flooding

Let probability $\pi 4$ represents Hydropower

And Let probability $\pi 5$ represents Water supply

$\mathrm{P}=\left(\begin{array}{rrrrr}0.5730659 & 0.085959885 & 0.2550143 & 0.0573066 & 0.028653295 \\ 0.91922845 & 0.020494274 & 0.022604 & 0.0241109 & 0.013562387 \\ 0.88069414 & 0.043383948 & 0.0281996 & 0.032538 & 0.015184382 \\ 0.30141844 & 0.354609929 & 0.1595745 & 0.0797872 & 0.104609929 \\ 0.34653465 & 0.185643564 & 0.1980198 & 0.0866337 & 0.183168317\end{array}\right)$

These Probabilities in the matrix were calculated by the formula:

$$
\hat{P}_{i j}=N_{i j} / \sum_{j=0}^{k} N_{i j} \text {, }
$$

Where $\mathrm{N}_{\mathrm{ij}}$ is the number of observed transitions from state $\mathrm{i}$ to $\mathrm{j}$. 
Then the Markov process equations can be stated as follows:

A stationary distribution of a Markov chain is a probability distribution that remains unchanged in the Markov chain as time progresses. Typically, it is represented as a row vector $\pi$ whose entries are probabilitysumming to 1 , and given transition matrix $\mathrm{P}$, it satisfies

$$
\pi \mathrm{P}=\pi
$$

in other words, $\pi$ is invariant by the matrix P.

Ergodic Markov Chains have a unique stationary distribution, and absorbing Markov chains have stationary distribution with nonzero elements only in absorbing states. The stationary distribution gives information about the stability of a random process and in certain cases describes the limiting behavior of the Marknv chain Note that the limiting distribution does not depend on the number of population within the Rir Equation 18 lat is why the researcher haschosen to work with a certain percentage of the population [1\%].Th

$0.573066 \mathrm{X} \pi 1+0.08595989 \pi 2+0.25501433 \pi 3+0.0573066 \pi 4+0.0286533 \pi 5=\pi 1$

$0.919228 \pi 1+0.02049427 \pi 2+0.02260398 \pi 3+0.0241109 \pi 4+0.01356239 \pi 5=\pi 2$

$0.080694 \pi 1+0.04338395 \pi 2+0.02819957 \pi 3+0.032538 \pi 4+0.01518438 \pi 5=\pi 3$

$0.080694 \pi 1+0.04338395 \pi 2+0.02819957 \pi 3+0.032538 \pi 4+0.01518438 \pi 5=\pi 4$

$0.346535 \pi 1+0.18564356 \pi 2+0.1980198 \pi 3+0.0866337 \pi 4+0.18316832 \pi 5=\pi 5$

$$
\pi 1+\pi 2+\pi 3+\pi 4+\pi 5=1
$$

\subsection{Markov Chain Analysis}

The equations having satisfied Markova homogeneous chain are analyzed by Markov steady state. There two methods for solving the infinite-stage problem. The first method calls for evaluating all possible stationary polices of the decision problem. This is equivalent to an exhaustive enumeration process and can be used only if the number of stationary policies is reasonably small.The second method, called policy iteration, is generally more effective because it determines the optimum policy iteratively.Conversely, the second method was adopted for this research work, using Microsoft Excel Power Matrix, developed by Charles E. Ebelings [2001] of University of Dayton.However, Table 5.3, 5.4 and 5.5 were all generated using Microsoft Excel Power Matrix.

Table 3: Matrix-P, raised [Iterated] to the power 5

\begin{tabular}{|l|l|l|l|l|l|}
\hline State of Nature & \multicolumn{5}{|c|}{ Objectives } \\
\hline Purposes & $\begin{array}{l}\text { Economic } \\
\text { efficiency } \\
\text { allow[Billion } \\
\text { Naira] }\end{array}$ & $\begin{array}{l}\text { Regional } \\
\text { economy }\end{array}$ & $\begin{array}{l}\text { State } \\
\text { economic } \\
\text { distribution }\end{array}$ & $\begin{array}{l}\text { Social } \\
\text { wellbeing }\end{array}$ & Environment \\
\hline Navigation & 0.63895267 & 0.08956123 & 0.185548887 & 0.051933549 & 0.03400349 \\
\hline Tourism & 0.64035577 & 0.08946399 & 0.184386119 & 0.051819485 & 0.03397448 \\
\hline Flooding & 0.64023006 & 0.0894737 & 0.184487805 & 0.051829778 & 0.03397854 \\
\hline Hydropower & 0.63800871 & 0.0896538 & 0.186260611 & 0.052012138 & 0.0340647 \\
\hline Water supply & 0.63871545 & 0.08964735 & 0.185564309 & 0.051957671 & 0.03411515 \\
\hline & & & & &
\end{tabular}

Table 4: Matrix- $P$, raised to the power 10

\begin{tabular}{l|l|l|l|l|l|}
\hline State of Nature & \multicolumn{5}{|c|}{ Objectives } \\
\hline Purposes & $\begin{array}{l}\text { Economic } \\
\text { efficiency } \\
\text { allow[Billion } \\
\text { Naira] }\end{array}$ & $\begin{array}{l}\text { Regional } \\
\text { economy }\end{array}$ & $\begin{array}{l}\text { State } \\
\text { economic } \\
\text { distribution }\end{array}$ & $\begin{array}{l}\text { Social } \\
\text { wellbeing }\end{array}$ & Environment \\
\hline Navigation & 0.63925821 & 0.08954401 & 0.18528533 & 0.051908977 & 0.03400324 \\
\hline Tourism & 0.63925672 & 0.0895441 & 0.185286596 & 0.0519091 & 0.03400326 \\
\hline Flooding & 0.63925689 & 0.08954411 & 0.185286492 & 0.051909089 & 0.03400326 \\
\hline Hydropower & 0.63925922 & 0.08954395 & 0.18528454 & 0.051908903 & 0.03400323 \\
\hline Water supply & 0.63925833 & 0.08954401 & 0.185285226 & 0.05190897 & 0.03400325 \\
\hline & & & & &
\end{tabular}


Vol.11, No.2, 2019

Table 5: Matrix- $P$, raised to the power 50

\begin{tabular}{|l|l|l|l|l|l|}
\hline State of Nature & \multicolumn{5}{|c|}{ Objectives } \\
\hline Purposes & $\begin{array}{l}\text { Economic } \\
\text { efficiency } \\
\text { allow[Billion } \\
\text { Naira] }\end{array}$ & $\begin{array}{l}\text { Regional } \\
\text { economy }\end{array}$ & $\begin{array}{l}\text { State } \\
\text { economic } \\
\text { distribution }\end{array}$ & $\begin{array}{l}\text { Social } \\
\text { wellbeing }\end{array}$ & Environment \\
\hline Navigation & 0.63925797 & 0.08954403 & 0.185285613 & 0.051908996 & 0.03400324 \\
\hline Tourism & 0.63925791 & 0.08954402 & 0.185285613 & 0.051909 & 0.03400324 \\
\hline Flooding & 0.63925791 & 0.08954403 & 0.185285598 & 0.051908996 & 0.03400325 \\
\hline Hydropower & 0.63925797 & 0.08954403 & 0.185285613 & 0.051909 & 0.03400324 \\
\hline Water supply & 0.63925791 & 0.08954402 & 0.185285613 & 0.051908996 & 0.03400325 \\
\hline
\end{tabular}

Looking at each column [1-5] of Table 4\&5, it appears to be the same i.e. the iteration has reached a steady state and can no longer change; this can also be called optimum solution or values.

Table 6: River Basin Allocation

\begin{tabular}{|l|l|l|l|}
\hline Purposes & $\pi_{i}$ & Percentage Allocation & $\begin{array}{l}\text { Allocation based on N100 } \\
\text { Billion Naira }\end{array}$ \\
\hline $\begin{array}{l}\text { Economic efficiency } \\
\text { allow[Billion Naira] }\end{array}$ & 0.63925797 & $64 \%$ & N63.925797b \\
\hline Regional economy & 0.08954403 & $9 \%$ & N8.954403b \\
\hline State economic distribution & 0.185285613 & $19 \%$ & N18.5285613b \\
\hline Social wellbeing & 0.051908996 & $5 \%$ & N5.1908996b \\
\hline Environment & 0.03400324 & $3 \%$ & N3.400324b \\
\hline
\end{tabular}

Table 7: Purposes verses Allocations

\begin{tabular}{l|l}
\hline Objective & Allocation \\
\hline Economic efficiency allow[Billion Naira] & 63.925797 \\
\hline Regional economy & 8.954403 \\
\hline State economic distribution & 18.5285613 \\
\hline Social wellbeing & 5.1908996 \\
\hline Environment & 3.400324 \\
\hline
\end{tabular}




\section{Allocation of resources to Objectives}

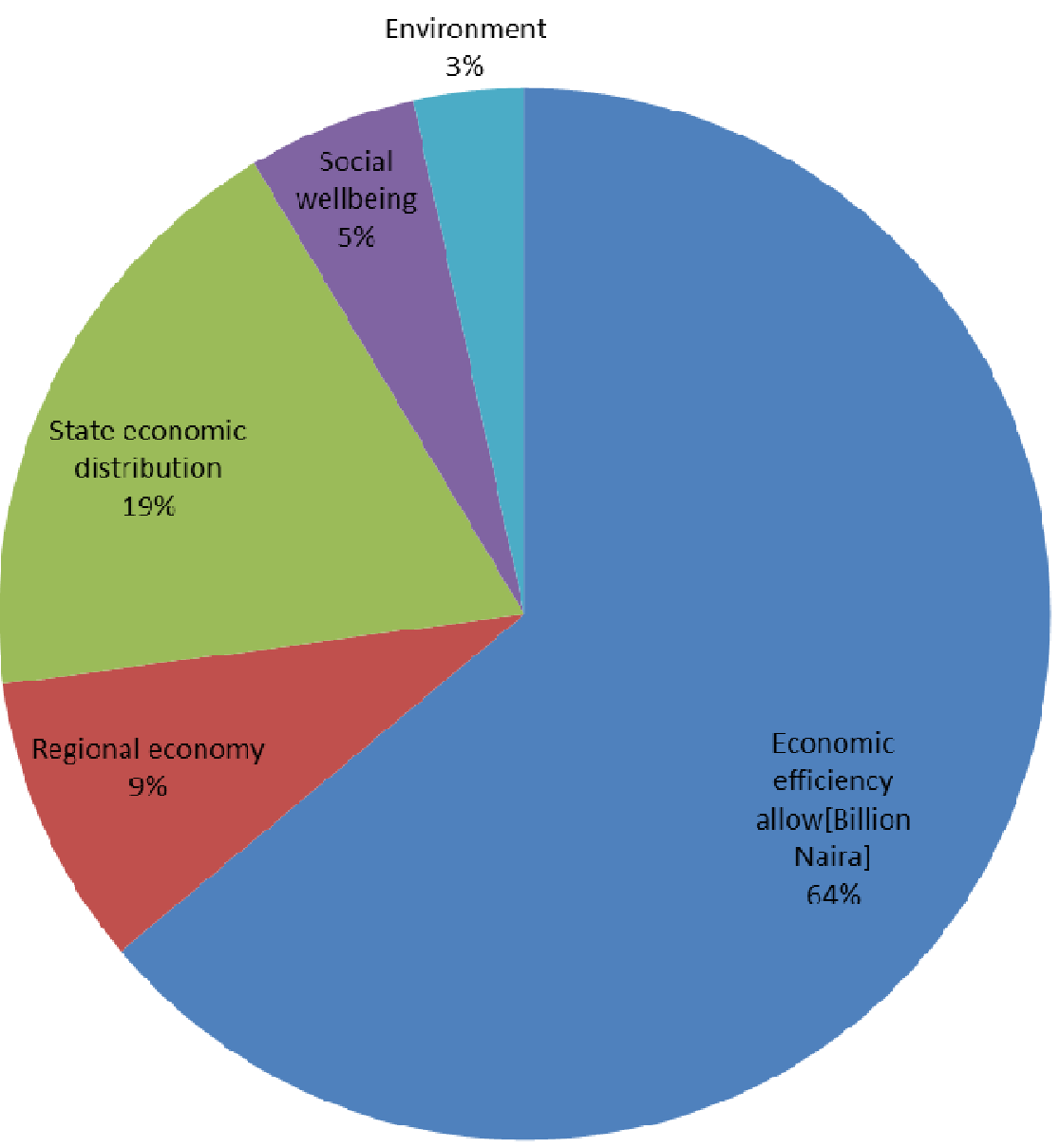

Figure 1: River Basin Purposes Allocation in percentage 


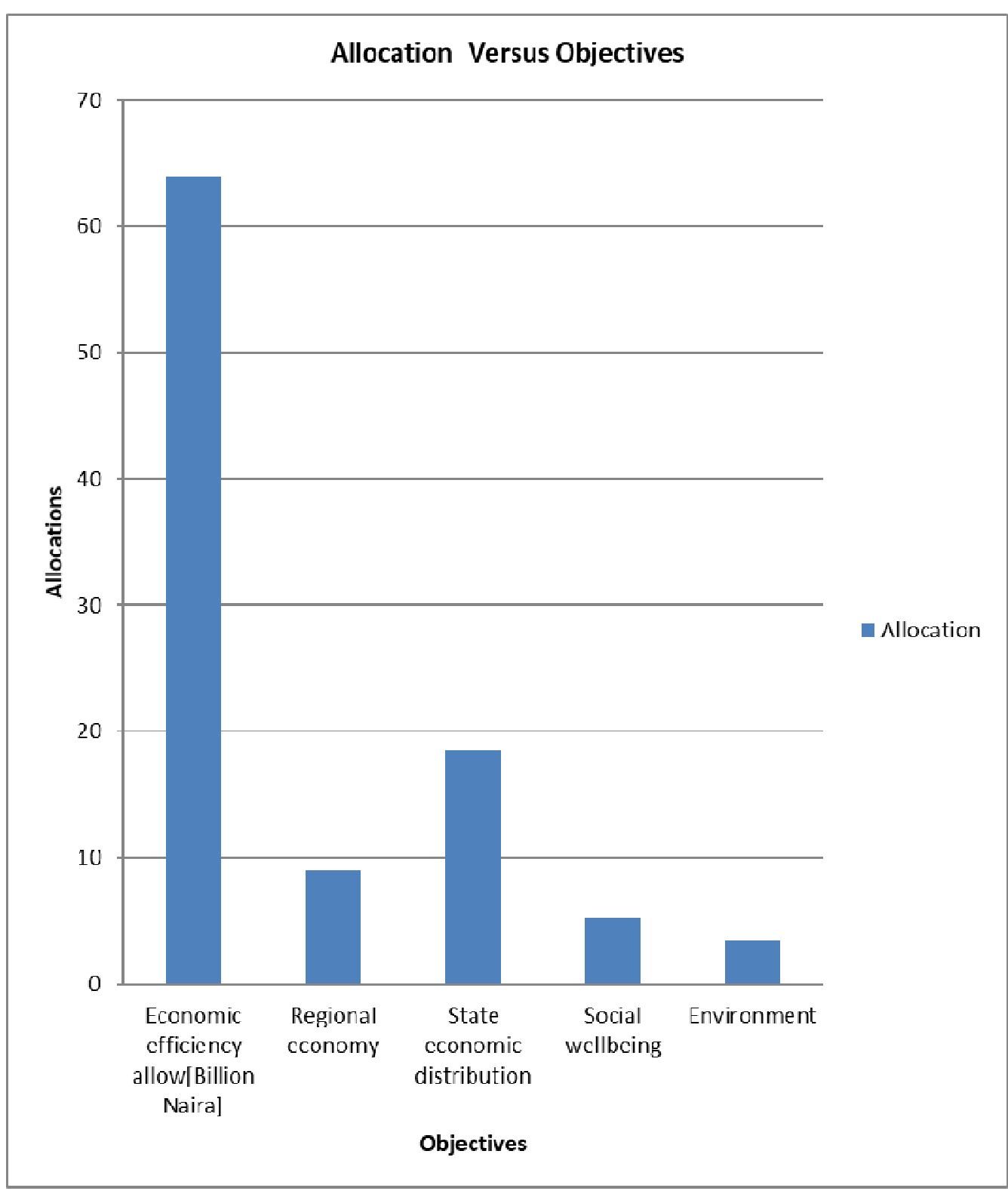

Figure 2: River Basin Purposes Allocation in Billions of Naira

\subsection{Contingency Coefficient And Its Associates}

Chi-Square $\left(\mathbf{X}^{2}\right)$ Contingency Test: The Chi-square test is a measure of relationships, association or independence. Introduced by Karl Pearson in 1990, the chi-square test is probably the best known and the most important of all non parametric method. It involves a measure of reliability by comparing observed frequency distribution failure mode with theoretical or expected distribution failure when that hypothesis is false. Non-parametric tests process the advantage of being fairly robust with respect to violations of assumptions having more power-efficiency (the power of a test relative to the sample size which permits one to compare the power of two different statistical tests. The power of a statistical test is then probability that the test will correctly reject the null hypothesis when that hypothesis is false) and sometimes providing more information about a phenomenon (i.e. interactions in the analysis of variance).

There are five basic conditions that must be met for Chi-square analysis to be validly applied. These are (a) the sample observations are independent of each other (b) sample data are drawn at random from the population (c) Sample data are expressed in original unites. (d) The sample should contain at least 50 observations. (e) There 
should be not less than five observations in any one cell. (f) Not more than $20 \%$ of the expected frequency should be less than 5 .

The $\mathrm{X}^{2}$ can be used to treat data which are classified into nominal, non-ordered categories; it can also be employed with numerical data. The researcher may wish, however to analyze such data with more powerful parametric test. But for nominal data, few alternatives to $\mathrm{X}^{2}$ analysis exist. The basic computation equation for $\mathrm{X}^{2}$ is given below:

\section{$x^{2}=\sum$ (Observed frequency- Expected frequency) \\ Expected frequency}

$x^{2}=\frac{\sum(0 \quad \mathbf{E})^{2}}{E}$

Equation 19

It should be noted that whenever $\mathrm{X}^{2}$ is calculated from ( 1 by 2 ) or ( 2 by 2 ) cell tables( instances in which the degree of freedom is one ) an adjustment known as Yates correction for continuity must be employed. To use this correction a value of 0.5 is subtracted from the absolute value (irrespective of algebraic sign) of the numerator contribution of each cell.

\section{$x^{2}=\frac{\sum \text { (Observed frequency }- \text { Espected frequency) }-0.5}{\text { Expected frequency }}$}

4 Contingency Coefficient, $\mathrm{C}$ is given by

$\mathrm{C}=\sqrt{\mathrm{X}^{2} / \mathrm{N}+\mathrm{X}^{2}}$

Equation 20

Where $\mathrm{C}=$ Contingency Coefficient

$\mathrm{X}^{2}=$ Chi-square

$\mathrm{N}=$ Grand total of subjects or cases

5 Correlation of Attributes

The degree to which one of the attributes depend upon is associated with or related to the other attribute is referred to as correlation of attributes. In the $\mathrm{k} x \mathrm{k}$ Contingency the correlation of attribu

$r=\sqrt{\mathrm{X}^{2} / \mathrm{N}(\mathrm{K}-1)}$

Equation 21

For a 2 X 2 table the correlation attribute is called tetra choric.

\subsection{Contingency and Reliability Test}

Contingency and reliability in this paper is another alternative method of testing null hypothesis, the paper assesses the relationship and test the null hypothesis on:

"There is a relationship between the Watershed Purposes and Objectives" 
Table 8: Observed Contingency Table

\begin{tabular}{|l|r|r|r|r|r|r|}
\hline $\begin{array}{l}\text { State of } \\
\text { Nature }\end{array}$ & \multicolumn{7}{|c|}{ Course of Action } \\
\hline & & & & & \\
\hline Irrigation & 2 & 0.3 & 0.89 & 0.2 & 0.1 & 3.49 \\
\hline Hydropower & 30.5 & 0.68 & 0.75 & 0.8 & 0.45 & 33.18 \\
\hline Water supply & 20.3 & 1 & 0.65 & 0.75 & 0.35 & 23.05 \\
\hline Recreation & 1.7 & 2 & 0.9 & 0.45 & 0.59 & 5.64 \\
\hline $\begin{array}{l}\text { Erosion } \\
\text { Control }\end{array}$ & 1.4 & 0.75 & 0.8 & 0.35 & 0.74 & 4.04 \\
\hline & 55.9 & 4.73 & 3.99 & 2.55 & & 69.4 \\
\hline
\end{tabular}

Step I: Calculation of the expected contingency table using the formula:

Ce:li $e_{j}=\frac{\text { ith Row Total } \mathrm{X} \text { th Column Total }}{\text { frrand Total }}$

Where $\mathrm{I}=$ is the $\mathrm{i}^{\text {th }}$ and

$$
\mathrm{J}=\text { is the } \mathrm{j}^{\text {th }} \text { column }
$$

A, B, C, ...... . Y $=\frac{\text { ith Row Total } X \text { jth Column Total }}{\text { Grand Total }}=$ Cellij Values in table Below:

Table 9: Expected contingency Table

\begin{tabular}{|r|r|r|r|r|r|}
\hline 2.81111 & 0.237863 & 0.20065 & 0.128235 & 0.112143 & 3.49 \\
\hline 26.72568 & 2.261403 & 1.907611 & 1.21915 & 1.066159 & 33.18 \\
\hline 18.56621 & 1.570987 & 1.325209 & 0.846938 & 0.740656 & 23.05 \\
\hline 4.542882 & 0.384398 & 0.324259 & 0.207233 & 0.181228 & 5.64 \\
\hline 3.254121 & 0.275349 & 0.232271 & 0.148444 & 0.129816 & 4.04 \\
\hline 55.9 & 4.73 & 3.99 & 2.55 & 2.23 & 69.4 \\
\hline
\end{tabular}

StepII: Computation of Chi-square using the formula:

$x^{2}=\frac{\Sigma(\mathrm{O}-\mathrm{E})^{2}}{\mathrm{E}}$ 
Table 10: Chi-square Table

\begin{tabular}{|c|c|c|c|c|}
\hline $\mathrm{O}$ & E & 0 -E & $(0-E)^{\wedge} 2$ & $(0-E)^{\wedge} 2 / E$ \\
\hline 2 & 2.81110951 & -0.81111 & 0.65789864 & 0.234035222 \\
\hline 0.3 & 0.237863112 & 0.062137 & 0.00386099 & 0.016231995 \\
\hline 0.89 & 0.200649856 & 0.68935 & 0.47520362 & 2.368322763 \\
\hline 0.2 & 0.12823487 & 0.071765 & 0.00515023 & 0.040162507 \\
\hline 0.1 & 0.112142651 & -0.01214 & 0.00014744 & 0.00131479 \\
\hline 30.5 & 26.72567723 & 3.774323 & 14.2455123 & 0.533027179 \\
\hline 0.68 & 2.261403458 & -1.5814 & 2.5008369 & 1.105878249 \\
\hline 0.75 & 1.907610951 & -1.15761 & 1.34006311 & 0.702482397 \\
\hline 0.8 & 1.219149856 & -0.41915 & 0.1756866 & 0.14410583 \\
\hline 0.45 & 1.066158501 & -0.61616 & 0.3796513 & 0.356092737 \\
\hline 20.3 & 18.56621037 & 1.73379 & 3.00602647 & 0.161908457 \\
\hline 1 & 1.570987032 & -0.57099 & 0.32602619 & 0.207529524 \\
\hline 0.65 & 1.325208934 & -0.67521 & 0.4559071 & 0.344026585 \\
\hline 0.75 & 0.84693804 & -0.09694 & 0.00939698 & 0.011095243 \\
\hline 0.35 & 0.74065562 & -0.39066 & 0.15261181 & 0.206049626 \\
\hline 1.7 & 4.542881844 & -2.84288 & 8.08197718 & 1.779041907 \\
\hline 2 & 0.384397695 & 1.615602 & 2.61017081 & 6.790287368 \\
\hline 0.9 & 0.324259366 & 0.575741 & 0.33147728 & 1.022259686 \\
\hline 0.45 & 0.207233429 & 0.242767 & 0.05893561 & 0.284392378 \\
\hline 0.59 & 0.181227666 & 0.408772 & 0.16709482 & 0.922016076 \\
\hline 1.4 & 3.254121037 & -1.85412 & 3.43776482 & 1.05643422 \\
\hline 0.75 & 0.275348703 & 0.474651 & 0.22529385 & 0.818212873 \\
\hline 0.8 & 0.232270893 & 0.567729 & 0.32231634 & 1.387674253 \\
\hline 0.35 & 0.148443804 & 0.201556 & 0.0406249 & 0.273671915 \\
\hline 0.74 & 0.129815562 & 0.610184 & 0.37232505 & 2.868107974 \\
\hline 69.4 & 69.4 & 0.00 & 39.38 & 23.63436176 \\
\hline
\end{tabular}

Contingency coefficient, $\mathrm{C}$ is given by

$\mathrm{C}=\sqrt{\mathrm{X}^{2} / \mathrm{N}+\mathrm{X}^{2}}$

Where $\mathrm{C}=$ Contingency Coefficient

$\mathrm{X}^{2}=$ Chi-square

$\mathrm{N}=$ Grand total of subjects or cases

$\mathrm{X}^{2}=\mathbf{2 3 . 6 3 4 3 6 1 7 6}$

$\mathrm{N}=69.4$

$C=\sqrt{23.63436176 / 69.4+23.63436176}$

$\mathrm{C}=0.504$, the maximum Contingency coefficient can go is 0.8 .

Therefore $\quad \mathrm{C}=0.653 / 0.8$

$\mathrm{C}=0.63$ 
Correlation of attributes $r$, is given as:

$$
\begin{aligned}
& r-\sqrt{\mathrm{X}^{2} / \mathrm{N}(\mathrm{K}-1)} \\
& \mathrm{r}=\sqrt{23.63430176 / 69.4(5 \quad 1)}
\end{aligned}
$$

$$
\mathrm{r}=0.292=0.3
$$

\subsection{Presentation of Results.}

The Contingency of the raw data is $=0.63$. The correlation of attributes of the raw data $=0.3$. The $\mathrm{X}^{2}$ value 23.63436176is interpreted from the $X^{2}$ table of probability values at 0.10 level of significance. The degree of freedom necessary to intercept $X^{2}$ values are always determined from the frequency table by the number of rows minus one times the number of columns minus one $(r-1)(c-1)$ i.e. $(5-1)(5-1)=16$

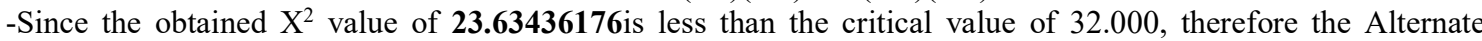
Hypotheses is accepted. i.e.: $X^{2}(\mathbf{2 3 . 6 3 4 3 6 1 7 6})<X^{2}{ }_{0.10}(32.000)$. Therefore the Alternate Hypothesis' saccepted, a clear indication that there is a relationship between the watershed purposes and the Objectives/Benefits.

-Therefore there is relationship between the state of the system (Dam Purposes) and the Dam Objectives.

-The Chi Square was not based on a fictitious data, in the case of Markov Decision Modeling in Niger Delta River Basin.

\section{1analysis of Variance[Anovar]}

The Pearson Product Moment Correlation Coefficient often referred to as the Pearson $\mathrm{R}$ tests, is a statistical formula that measures the strength between variables and relationships. To determine how strong the relationship is between two variables, you need to find the coefficient value, which can range between -1.00 and 1.00. The computations are done as shown in Table 11 using equation 23 and results displayed graphically in Figure 3

$$
r=\frac{\sum X Y}{\sqrt{\Sigma\left(X^{2}\right)\left(Y^{2}\right)}}
$$

The analysis of variance in this reseach work can be done using the following methods:

(i) Let consider one of the river basin Objectives, at $1^{\text {st }}$ Iteration and $50^{\text {th }}$ Iteration. Using Pearson Product Moment Correlation Coefficient, on the River basin Objective Initial benefits values and the $50^{\text {th }}$ Iteration benefits values, $r=0.9851$, this infer a perfect positive relation between Initial Values and iterative values.. of the river basin objectives under Navigation [See Table 11]

\begin{tabular}{|c|c|c|c|c|c|c|c|}
\hline \multicolumn{8}{|c|}{ Pearson Product Moment Correlation Coefficient[Pearson r] } \\
\hline \multicolumn{8}{|c|}{ CORRELATION COEFFICIENTS[r]-COMPUTATION } \\
\hline R.B. Objectives & $\begin{array}{l}\text { Initial } \\
\text { iteration } \\
\text { Benefits } \\
\end{array}$ & $\begin{array}{l}\mathbf{5 0}^{\text {th }} \\
\text { Iteration } \\
\text { Benefits } \\
\end{array}$ & 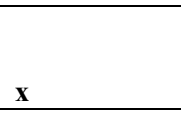 & $\mathbf{Y}$ & $\mathbf{X y}$ & $\mathbf{x}^{\wedge} \mathbf{2}$ & $\mathbf{y}^{\wedge} \mathbf{2}$ \\
\hline $\begin{array}{l}\text { Economic } \\
\text { Efficiency }\end{array}$ & 0.573066 & 0.639258 & 0.323066 & 0.389258 & 0.125756 & 0.104372 & 0.151522 \\
\hline $\begin{array}{l}\text { Regional } \\
\text { Distribution }\end{array}$ & 0.08596 & 0.089544 & -0.16404 & -0.16046 & 0.026321 & 0.026909 & 0.025746 \\
\hline State distribution & 0.255014 & 0.185286 & 0.005014 & -0.06471 & -0.00032 & $2.51 \mathrm{E}-05$ & 0.004188 \\
\hline Social Well-being & 0.057307 & 0.051909 & -0.19269 & -0.19809 & 0.038171 & 0.037131 & 0.03924 \\
\hline \multirow[t]{3}{*}{ Environment } & 0.028653 & 0.034003 & 0 & 0 & 0.189924 & 0.168437 & 0.220696 \\
\hline & 1 & 1 & & & & & \\
\hline & & & $\mathbf{r}$ & 0.9851 & & & \\
\hline
\end{tabular}

The initial benefits Iteration and $50^{\text {th }}$ Iteration benefits values were correlated using Pears Equation 23 ation coefficient formula and $\mathrm{r}$ was determined as $\mathbf{0 . 9 8 5 1}$ in table 11 and the graph representec

Table 11: Initial Benefits values and $50^{\text {th }}$ Iterative benefits value 


\subsection{Model Validation}

The initial iteration and $50^{\text {th }}$ iteration were plotted, as in column 2and 3 of table 11 for the validation of the model. Therefore $\mathrm{R}=0.985$

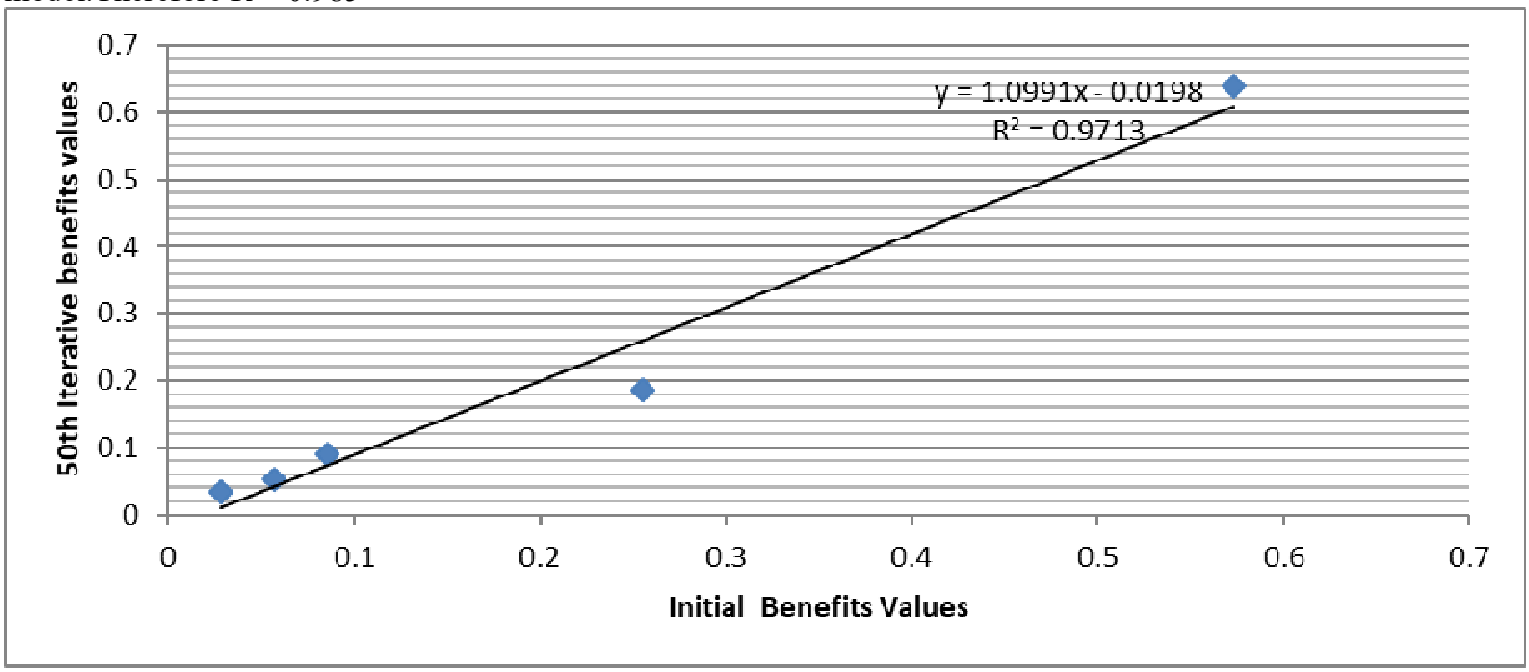

Figure 3: Relationship between Initial and projected values of River Basin Objectives.

Graph Equation: $\mathrm{y}=1.099 \mathrm{x}-0.019$

$\mathrm{R}^{\wedge} 2=0.971$

Therefore $\mathrm{R}=0.985393$

\subsection{Conclusion and Recommendation}

Based on the findings and conclusions reached on the study the following recommendations are made:

Niger delta has more water available; therefore it is recommended that Hydropower in this region should be considered and encouraged because of it immediate and long term benefits when compared to gas powered electric plants. Also clean environment should be embraced for a healthy land, water and air; and in turn increase the level of tourism as well as reduces flooding caused by environmental abuse.

\subsection{Contribution to Knowledge}

The study can provide an organized baseline for future work, mainly in obtaining superior estimates for institutional water use and planning by the aid of Markovian decision theory. However, the findings of the study can be vital input into the demand management process for long term sustainable water supply within Niger Delta River Basin and beyond.

\section{References}

Aaron, D. (2016). A Complete Guide To The Bayes Factor Test.

Adrian, E. R. (1964). University of Washington(1994), Technical Report no. 254 Department of Statistics, University of Washington Technical Report no. 571.

Agnes, I. (). Who should govern our watersheds:" A case study from Northern Cross River State Nigeria."

Alene,A.D..et al. (2009) The economic and poverty impacts of maize research in West and Central Africa. Agricultural Economics, 40: 535-550.

Amy, H. and Leaf, G. (2018). Climate of Obudu, Nigeria, traveltips.usatoday.com

Ayoade, J.O. (1983) Introduction to Climatology for the tropics. Spectrum book Ltd, Ibadan.

Bagley, L., Jay, M.., Rolaad, W. J.aad Cleve, H. M. (1964) . Water yield s iaUtah . Utah Agricultural Experiment Station, Spec ial Report 18 . September 1964. 
Balasubramanian, V., Sie, M., Hijmans, R., Otsuka, K., (2007).Increasing rice production in sub-Saharan Africa: challenges and opportunities.Advances in agronomy,94:55-133.

Barbey, A. K. \&Sloman, S. A. (2007). Base-rate respect: From ecological rationality to dual processes. Behavioral and Brain Sciences, 30: 241-254.

Baudron et al, (2015). Re-examining appropriate mechanization in Eastern and Southern Africa: two-wheel tractors, conservation agriculture, and private sector involvement, Food Security, May 2015

Bouis, H.E., Hotz, C., McClafferty, B., Meenakshi, J.V. \&Pfeiffer, W.H. (2011).Biofortification: a new tool to reduce micronutrient malnutrition. Food Nutr.Bulletin,32: S31-40.

Bullock, B. J . \&Logaa, S. H. (1969) . A model for decision making under uncertainty .Agricultural Ecoaomics Research,21(4) : 857.

Carsoa , C. W. , Alessi, J. \& Mickelson, R. H. (1959). Evapotranspiration and yield of corn as influenced by moisture Level, nitrogen fertilization and plant density .The Soil Science Society of America.Soil Science Society of America Proceedings, Vol. 28 .

Chernoff, H.\& Lincoln, E. M. (1959). Elementary decision theory . John Wiley \& Sons, Inc., New York.

Christensen, R. (2005). Testing Fisher, Neyman, Pearson, and Bayes.American Statistician, 59: 121-126.

Criddle, 1. D. , Karl, H. and Lynman, S. (1962). Willardson.Consumptive use and water requiremeats for Utah.Office.of State Engineer, Technica 1 Publication No . 8.

Daniel, P. et al. (2005). Water Resources System Planning \& Management: Introduction to Methods and Applications, p 368. Studies and Report in Hydrology, UNESCO.

Davis, L. H. (1965). Maximizing incomes from Sevier County farms, 1949-58 . Utah Experiment Statioa, Bulletin 451.

Dean, G.W. (1966). Decision theory models in range Livestock research . Economic research in the use and development of range $r$ esources . Adjustments in the range Livestock industry . Report No . 8, Proceedings WAERC Range Committee Meeting, San Francisco, California . August 1966.

Draper, N. R. and Smith, H. (1966). Wiley \& Sons, Inc ., New York. Applied regression analysis.

Eidman, V. R., Gera ld, W. D. \& Harold, O. (1967). Carter .An application of statistic decision theory to commercial turkey production.Journal of Farm Economics,49(4) : 852 . 1967.

Eme L.C. (2009). Flood Disaster and their Optimal Alleviations Strategy in Nigeria. Journal of Science and Technology Research, 8(3): $19-25$.

Eme L.C. (2009). Logical Cost Sharing in Markovian Decision Theory.InternationalJournal of Engineering Science, 2(1): $37-45$.

Eme L.C. (2010). The Quality of Sandcrete Blocks as a Building Component and the Implications for Sustainable Development in the Building Industry-A Case Study of Blocks from Factories Across Abeokuta, Ogun State, Nigeria. InternationalJournal of Civil Engineering, 2(1): 57 - 59.

Eme L.C. (2010). Waste Water Treatment and Re-use Scheme for Farm Settlement Communities in Nigeria. Journal of Science and Technology Research, 9(2): 76 - 78.

Eme L.C. (2010). Water Resources Engineering Development Scheme: Optimal Strategy for Multipurpose/Multi-objective Water Resources Engineering Development Scheme. InternationalJournal of Civil Engineering, 2(1): 49 - 56.

Eme L.C. (2010). Water Resources Engineering Development Scheme: Optimal Strategy for Multipurpose/Multi-objective Water Resources Engineering Development Scheme. African Journal of Engineering Research and Development, 3(3): 27 - 33.

Eme L.C. (2011). Application of Markovia Decision Theory in Multi-purpose/Multi-Objective Dam Development Project Optimization.Journal of Research in Engineering, 8(2): 70-74.

Eme L.C. (2012). A Practical Model for Rehabilitation of Nigerian Hybrid Electric Power Generation.African Journal of Engineering Research and Development, 5(1): 13 - 20.

Eme L.C. (2012). Rural Water Supply Scheme Model in Africa: A Case Study of Eastern States of Nigeria. African Journal of Engineering Research and Development, 5(2): 123 - 20.

Eme, (2015).Simulation modeling in Markovian Decision theory.A Case Study of the Gardner's Problem.American Academic \& Scholarly Research Journal, 7(4): 177 - 186.

Eme, L.C. \&Anyata, B.U. (2015). Economic Environmental Impact and Evaluation Model: A Case Study of Hydro-power/Water Supply/Railway. American Academic \& Scholarly Research Journal, 7(4): 78 85.

Eme, L.C. \&Anyata, B.U. (2015). Model of Environmental Qualityand Recreation: A Case Study of River rine Regions of Nigeria. American Academic \& Scholarly Research Journal, 7(4): 71 - 77.

Eme, L.C. (2004). "Application of Markovian Decision Theory in Multi-Purpose/Multi-Objective Water Resources Planning and Management”, Post Graduate Project(M.Eng.), NnamdiAzikiwe University Awka. 
Eme, L.C. (2004). “Application of Markovian Decision Theory in Multi-Purpose/Multi-Objective Water Resources Planning and Management”, Post Graduate Project(M.Eng.), NnamdiAzikiwe University Awka.

Eme, L.C. (2004). “Application of Markovian Decision Theory in Multi-Purpose/Multi-Objective Water Resources Planning and Management", Post Graduate Project (M.Eng.), NnamdiAzikiwe University Awka.

Eme, L.C. (2011) "Simulation Modeling in Markovian Dec ision Theory-A Case Study of The Gardeners's Problem" Post Graduate Seminar(PhD), Anamabra State University Uli.

Eme, L.C. (2011) "Simulation Modeling in Markovian Dec ision Theory-A Case Study of The Gardeners's Problem" Post Graduate Seminar(PhD), Anamabra State University Uli.

Eme, L.C. (2011). "Simulation Modeling in Markovian Decision Theory-A Case Study of The Gardeners's Problem" Post Graduate Seminar (PhD), Anambra State University Uli.

Eme, L.C. (2012). "Simulation Modeling in Markovian Decision Theory in Multi-Purpose/Multi-Objective of River Basin Engineering Development, Planning and Management-A Case Study of Anambra/Imo River Basin Nig" Post Graduate Thesis (PhD), Anambra State University Uli.

Eme, L.C. (2012). Infinite Stage Optimization Model for Reactivation of Nigerian River Basin as Alternative to over Dependence on Oil Exploration.

Eme, L.C. (2012). Model of Environmental Qualityand Recreation: A Case Study of River rine Regions of Nigeria. African Journal of Engineering Research and Development, 5(1): 122 - 127.

Eme, L.C. (2012). Simulation Modeling in Markovian Decision Theory in Multi-Purpose/Multi-objective River Basin Development Planning and Management. Outline paper for submission to the World Water Congress \& Exhibition.

Eme, L.C. (2015). Finite Stage Simulation Solution Modeling of Markovian Chain to Maintenance Management Problems for Nigerian River Basin Engineering Scheme.American Academic \& Scholarly Research Journal, 7(5): $45-52$.

Eme, L.C. (2015). Infinite Stage Simulation Model Optimization Solution using Exhaustive Enumeration Method for the Anambra/Imo River Basin Engineering Development Scheme, Nigeria. American Academic \& Scholarly Research Journal, 7(4): 55 - 61.

Eme, L.C.(2015). Interactive Optimization for Model and Prototype: A Case Study of the Twelve Nigerian River Basin Engineering Development Scheme. American Academic \& Scholarly Research Journal, 7(4): 55 -61 .

Eme, L.C.(2015). Simulation Optimization for Model and Prototype using Non Parametric Method: A Case Study ofAnambra/Imo River Basin Engineering Development Scheme. American Academic \& Scholarly Research Journal, 7(4): 63 - 61.

Eme, L.C. and Mbanusi, E.C. (2012). Fluid Structural Interactions: A case Study of Effect of Wind and Water Storms on Continuous Frame Structure using Classical Displacement Simulation Model.

Eme, L.C., Okonkwo, S.I. \&Egbulefu, R.A. ().Optimization modelling of quality of water in the pollution regions of Nigeria.

Enplan, G. (2004). Review of the public sector irrigation in Nigeria, Federal Ministry of Water Resources.

Esu E.O. et al (1996). "Geotechnical Characterisation of Obudu dam site, Obudu, South-eastern Nigeria."

Fisher and Wolfe (2012): Null Hypothesis Significance Testing and Bayesian Statistics Published by ePublications@bond, 2012.

Fisher and Wolfe(2012). Null Hypothesis Significance Testing and Bayesian Statistics, : http://epublications.bond.edu.au/ejsie/vol5/iss $3 / 3$

Gisser, M. (1969). Introduction to price theory. The Haddon Craftsman, Inc., Scranton, Pennsylvania. 1969.

Google Eath Pro (2018). CNES/Airbus Image LandSat/Copernicus.

Granger, C.W.J. \&Machina, M.J. (2006).“Forcasting and Decision Theory”.Handbook of Economic Forcasting, Volume 1.

Haddock, J. L., Smith, P. B.,Downie, A. R. Alexander, J. T., Easton, B. E. \&Vernal V. (1959). The influence of cultura 1 practices in the quality of sugar beets .Amer.Soc .Sugar Bee t Tech.Proc .10 (4) : 290-301.

Hardaker, J. B., Huirne, R. B. M., Anderson, J. R., \& Lien, G. (2015).Coping with Risk in Agriculture, Applied Decision Analysis.CABI. 14.

Harold, M. (2015). Cereal Crops: Rice, Maize, Millet, Sorghum, Wheat

Heady, E.O (1952).Fcooomic.s of agriculL u ra 1 production and r.; * source use. Prt>nt i C'.t:.-llall , I nc" , Eng 1 ewo d Cl1 ffs , New Je rsey. 1952 .

Hiskey , H. H. \& Darwin, B. N. (1969). Bayes i an d c is i n theory: A tool for farm managers. Economi c Research Ctn t e r, Utah State Un iversity, Cent e r Study Paper 69- 10.

Hubbard, R., \&Bayarri, M..J. (2003). Confusion over measures of evidence(p's)versus errors( 15 's) in classical statistical testing. American Statistician, 57:171-182. 
Kahneman, D., \&Tversky, A. (1973).On the psychology of prediction.Psychological Review,80:237-251. 5.

Kruschke, J. K. (2011). Bayesian assessment of null values via parameter estimation and model comparison.Perspectives on Psychological Science, 6(3):299- 312..

Kruschke, J.K. (2010). Doing Bayesian data analysis: A tutorial introduction with R and BUGS. Burlington, MA: Academic Press.

Kurukulasuriya, P.\& Rosenthal, S. (2003). Climate change and agriculture: A review of impacts and adaptations. Paper No 91 in Climate Series, Agriculture and Rural Development and Environmental Department, World Bank, Washington, D.C; 2003

Lakawathana, S. (1970)."An Application of Statistical Decision Theory to Farm Management in Sevier County, Utah" (1970).All Graduate Theses and Dissertations.2927. https://digitalcommons.usu.edu/etd/2927.

Lecoutre, M.-P., Poitevineau, J., \&Lecoutre, B. (2003). Even statisticians are not immune to misinterpretations of null hypothesis significance tests. International Journal of Psychology, 38(1):37-45.

Lehmann, E. L. (1993). The Fisher, Neyman-Pearson theories of testing hypotheses: One theory or two? Journal of the American Statistical Association, 88, 1242-1249.

Less .W. (2011).History of Bayesian Theorm, retrived from the internet on 21/03/18 at 12:19 PM.

Lindley, D. (1987). The Probability approach to the treatment of Uncertainty in Artificial Intelligent and Expert System.Statistical Science, 2: 3-44.

Luce, D. R. and Howard, R. (1957). Gamt >E and dec i s tons . John Wi 1 ey\& Sons, lnc, New York, 1957.

Management" (2011).All Graduate Theses and Dissertations. 979.

Managemt.ntdectsion making, Report No , 5 P ceed ngs WAERC Range Committcr M c ting, Pullman, Washington, Augus 1958, and Logan , Utah , 1959

Mann, P. S. \&Lacke, C. J. (2010). Introductory Statistics (7th ed.). United States of America, Wiley \& Sons. 10. Nickerson, R. S. (2000). Null hypothesis significance testing: A review of an old and continuing controversy. Psychological Methods, 5: 241-301.

May, D.M. (). Th e Effects of various nitrogen and moistur $\sim 1 \mathrm{ev}$ e $1 \mathrm{~s}$ on the production of silage corn, gratn co $\mathrm{rn}$ and swee $\mathrm{t}$ corn, Ma s t e $\mathrm{r}$ thes is, Uta h State Un i v

McConne n, R. J .Dec ision t heory and range livestock op rations. Economics resarch in the us e and lopmnt of rang rtsources. Adjustmen $\mathrm{t} s$ in the range livestoc $\mathrm{k}$ indus t ryRe port No, 3, Proceed -WAE C Range Committ e Meeting, Ft . Co llins, Co lorado. Augus t 1961

McNamara, J. M., Green, R. F. \& Olsson, O. 2006.Bayes' theorem and its applications in animal behaviour.Oikos 112: 243-251.

Mitts , I. (1963) . Op t imum e nterpr i s e c ombination for $r$ e pr e senta - tivfarms in Sev i e r County, Utah . Ma ste $r$ th e s is, Utah State Un iversity, Lo gan, Ut $\sim \mathrm{h}$.

OECD/Food and Agriculture Organization of the United Nations, (2015).OECD-FAO Agricultural Outlook 2015, OECD Publishing, Paris.

Petri, N. (2011). Non-Linear Modeling with Bayesian Methods, University of Finland.

Reyna, V. F. (2004). How people make decisions that involve risk. A dualprocesses approach.Current Directions in Psychological Science, 13:60-66.

RicesOf Major Agricultural Commodities In Nigeria (National Averages In Naira Per Kilogram $(=\mathrm{N}=/ \mathrm{KG})))$ )https://www.cbn.gov.ng/devfin/prices.pdf

Robert E. K. (1994). Carnegie-Mellon University, Technical Report no. 571 Department of Statistics, CarnegieMellon University March 1993; Revision 3: July 6, 1994

Schlaifer, R. (1959). Probability and statistics for business decisions .McGr aw-Hill Book Company, Inc ., New York .

Sotos, A. E. C., Vanhoof, S., Van den Noortgate, W., \&Onghena, P. (2007). Students' misconceptions of statistical inference: A review of the empirical evidence from research on statistics education. Educational Research Review, 2: 98- 113.

Torres-Rua, A. F, (). "Bayesian Data-Driven Models for Irrigation Water

Uche N., Joshua, T.andRyan S. (2017). Grain and Feed Annual In Nigeria:Global Agricultural Information Network.

USDA, Production Estimates and Crop Assessment Division (PECAD) Foreign Agricultural Service (FAS) http://fas.usda.gov/pecad/pecad.html

Wagenmakers, E.-J.(2007). A practical solution to the pervasive problem of p values.Psychonomic Bulletin \& Review, 14:779-804. 